\title{
Protein haze formation in wines revisited. The stabilising effect of organic acids
}

\author{
Luís Batista ${ }^{\mathrm{a}, \mathrm{c}}$, Sara Monteiro ${ }^{\mathrm{a}, \mathrm{b}, \mathrm{c}}$, Virgílio B. Loureiro ${ }^{\mathrm{a}, \mathrm{c}}$, Artur R. Teixeira ${ }^{\mathrm{a}}$, Ricardo B. Ferreira ${ }^{\mathrm{a}, \mathrm{b}, \mathrm{c}, *}$ \\ ${ }^{a}$ Departamento de Botânica e Engenharia Biológica, Instituto Superior de Agronomia, Universidade Técnica de Lisboa, 1340-017 Lisboa, Portugal \\ ${ }^{\mathrm{b}}$ Disease \& Stress Biology Laboratory, Instituto de Tecnologia Química e Biológica, Universidade Nova de Lisboa, 2781-901 Oeiras, Portugal \\ ${ }^{c}$ CEV - Biotecnologia das Plantas, S.A., Rua José Vicente Gonçalves n` 8 H, Parque Industrial do Seixal, 2840-068 Aldeia de Paio Pires, Portugal
}

\section{A R T I C L E I N F O}

\section{Article history:}

Received 22 April 2009

Received in revised form 6 January 2010

Accepted 18 March 2010

\section{Keywords:}

Haze

Organic acids

Tartaric acid

Wine proteins

$\mathrm{X}$ factor

\begin{abstract}
A B S T R A C T
The effect on the wine protein haze potential of five organic acids commonly encountered in wines $(\mathrm{L}(+)-$ tartaric, $\mathrm{L}(-)$-malic, citric, succinic and gluconic acids) was assessed. All five acids, tested at $20 \mathrm{mM}$, reduced dramatically the haze potential of proteins, either in wine or dissolved in water, throughout the range of $\mathrm{pH}$ values typical of wines (i.e., from 2.8 through 3.8). Subtle differences among the acid effects did not correlate with the number of their carboxyl groups, but were attributed to electrostatic interactions that depend upon the acid $\mathrm{p} K_{\mathrm{a}}$ values, the protein $\mathrm{pI}$ values and the medium $\mathrm{pH}$. These results invalidate or question the validity of all experiments on wine proteins involving wine model solutions containing organic acids. Overall, the results obtained in the present work clearly indicate that organic acids with a common occurrence in wines exhibit a stabilising effect upon the haze potential of the wine proteins.
\end{abstract}

() 2010 Elsevier Ltd. All rights reserved.

\section{Introduction}

Protein precipitation in wines is increasingly regarded as a multifactorial process, with factors such as $\mathrm{pH}$, phenolic compounds and possibly others directly involved or modulating wine haze formation. Besides the proteins themselves and the wine $\mathrm{pH}$, there appears to be an absolute requirement for one or more as yet unknown non-proteinaceous wine components termed the $\mathrm{X}$ factor. Two different mechanisms for wine protein insolubility were recently demonstrated (Batista, Monteiro, Loureiro, Teixeira, \& Ferreira, 2009): one operating only at high $\mathrm{pH}$ values, resulting from reduced protein solubility at its $\mathrm{pI}$; another detected at all $\mathrm{pH}$ values, due to the $\mathrm{X}$ factor.

Organic acids derive not only from grapes (such as tartaric, malic, citric and gluconic acids), but also from specific metabolic events, for example the alcoholic fermentation, malolactic fermentation and ethanol oxidation, among others (such as succinic, lactic and acetic acids) (Ribéreau-Gayon, Glories, Maujean, \& Dubourdieu, 2006). Their concentrations in wines vary with the variety, environmental conditions and metabolic events occurring during winemaking and storage. Nevertheless, tartaric, malic and citric acids are present in wines in relatively abundant amounts, typically $3-5,1-2$ and $0.5-1 \mathrm{~g} / \mathrm{l}$, respectively (Ribéreau-Gayon et al.,

\footnotetext{
* Corresponding author at: Departamento de Botânica e Engenharia Biológica, Instituto Superior de Agronomia, Universidade Técnica de Lisboa, 1340-017 Lisboa, Portugal. Tel.: +351 213653416; fax: +351 213653238.

E-mail address: rbferreira@isa.utl.pt (R.B. Ferreira).
}

2006). Others, such as gluconic acid, accumulate when the grapes are infected with Botrytis, whereas up to $1 \mathrm{~g} / \mathrm{l}$ of succinic acid may be produced by yeasts (Ribéreau-Gayon et al., 2006).

Other organic acids may be encountered in wines, but in lower amounts, for example, galacturonic, glucuronic, citramalic, dimethylglyceric, pyruvic and $\alpha$-ketoglutaric acids (Belitz \& Grosch, 1992; Peynaud, 1999). Phenolic acids are also present in wines, most often in combination with other molecules, in amounts normally ranging between 10 and $20 \mathrm{mg} / \mathrm{l}$ for white wines. They include cinnamic acids (such as $p$-coumaric, caffeic and ferulic acids) and benzoic acids (such as $p$-hydroxybenzoic and gallic acids).

Regardless of their origin, organic acids are multifunctional molecules, mostly hydroxyacids with a polar and hydrophilic nature. They are usually quite reactive, readily or easily establishing bonds with other molecules. Thus, cinnamic acids form ester bonds with tartaric acid, remaining in residual amounts in the free form (Ribéreau-Gayon et al., 2006).

Crystallisation of tartrate salts is a major source of instability in wines, occurring spontaneously during both alcoholic fermentation and wine storage. Among others, cold stabilisation is a physical stabilisation process often performed to prevent the formation of crystals in the bottled wines (Blouin, Guimberteau, \& Audouit, 1979; Maujean, Sausy, \& Vallée, 1985; Vallée et al., 1995).

A number of wine components are commonly associated with the tartrate crystals. These wine constituents usually affect the crystal growth rate, since crystallisation kinetics are much slower in wines than in model ethanolic solutions of similar degree of saturation (Gerbaud, Gabas, Blouin, Pellerin, \& Moutounet, 1997; Rodriguez-Clemente \& Correa-Gorospe, 1988; Tanahashi, Nishino, 
\& Kazumoto, 1992). Their negative effect on crystal growth is attributed to their adsorption onto the growth sides of the crystal faces, blocking the integration of new units into the crystal lattice (Gerbaud et al., 1997; Maujean et al., 1985; Tanahashi et al., 1992).

Vernhet et al. (1999a) reported that caftaric, coutaric and 2-S-glutathionylcaftaric acids, all esters of tartaric acid, and polysaccharides (rhamnogalacturonans I and II, but not arabinogalactan-proteins) account for $0.2-0.8 \%$ of the crystal dry weight. Other phenolic compounds detected in tartrate crystals obtained from red wines were anthocyanins and tannins, particularly those exhibiting higher polymerisation degrees (Vernhet et al., 1999b).

Koch and Sajak (1959) were the first to report the presence of proteins in tartrate deposits. Subsequently, Correa-Gorospe and colleagues (1991a, 1991b) detected the presence of peptides and proteins in tartrates. Indeed, proteins, bearing a net positive charge at the wine $\mathrm{pH}$, may interact electrostatically with the crystal face, which possesses a net negative charge due to the presence of tartrate anions (Correa-Gorospe, Polo, Rodriguez-Badiola, \& Rodriguez-Clemente, 1991b). However, Correa-Gorospe, Polo, and Hernandez (1991a) reported that proteins comprise only a small proportion of the nitrogenous compounds present in tartrate crystals.

Overall, the studies reported so far show that organic acids, and tartaric acid in particular, form a series of bonds with other wine compounds, including proteins. Regarding other wine organic acids, such as malic, citric or succinic acids, no interaction with other wine molecules has been reported in the literature to be of significant technological importance. No studies have been published on the potential (either direct or indirect, positive or negative) effect of organic acids on wine protein instability. Using a model wine solution ( $12 \%$ ethanol and $4 \mathrm{~g} / \mathrm{l}$ tartaric acid), Pocock, Alexander, Hayazaka, Jones, and Waters (2007) tested the effect of several phenolic acids, including caffeic, caftaric, gallic and ferulic acids, on thaumatin instability and observed that no hazes formed after heating in any of the samples.

The great technological and economic importance of studying the interaction between wine components and wine proteins results from the fact that, under conditions that remain to be identified, the proteins in wines may precipitate, greatly affecting the clarity and stability of the wine (Ferreira, Monteiro, Piçarra-Pereira, Loureiro, \& Teixeira, 2004; Ferreira, Piçarra-Pereira, Monteiro, Loureiro, \& Teixeira, 2002). In this work, we have analysed a number of organic acids occurring in wine, some of which exhibit a modulating effect upon haze formation, interfering with protein precipitation and supporting the current view that protein haze formation in wines is a multifactorial process, while leaving the $\mathrm{X}$ factor to be identified.

\section{Materials and methods}

\subsection{Preparation of wine}

The varietal white wine used in this work was prepared from Arinto grapes (2006) as described before (Batista et al., 2009). The wine was divided into $100-\mathrm{ml}$ aliquots and stored at $-20^{\circ} \mathrm{C}$ until used. To avoid repeated thawing and freezing, a new aliquot was used for each experiment.

\subsection{Isolation of Arinto wine total protein}

The Arinto wine total soluble protein was isolated after separation from the wine lower molecular mass compounds and from the other high molecular mass polymers and obtained as a solid, freeze-dried powder, using the methodology described previously (Batista et al., 2009).

\subsection{Protein determination}

Protein in wine and samples was measured by a modification of the Lowry method (Bensadoun \& Weinstein, 1976), using bovine serum albumin as the standard. The Arinto wine used throughout this work was found to contain $280 \mathrm{mg}$ protein/l. When appropriate, protein concentrations were determined by the Bradford method (1976).

\subsection{Preparation of samples for turbidity measurements}

Arinto wine samples, containing $280 \mathrm{mg}$ protein/l, were thawed, centrifuged at $10,000 \mathrm{~g}$ for $5 \mathrm{~min}$ to remove insoluble particles and the $\mathrm{pH}$ adjusted to the appropriate values.

The dried powder containing the Arinto wine total protein, previously isolated as described above, was dissolved in enough water ( $\mathrm{pH}$ adjusted to 2.8) to give a final protein concentration of $280 \mathrm{mg} / \mathrm{l}$. The resulting solution was centrifuged at $10,000 \mathrm{~g}$ for $5 \mathrm{~min}$ and the supernatant used for protein quantification and the $\mathrm{pH}$ adjustment at selected values.

Whenever required, the Arinto $<3 \mathrm{kDa}$ component fraction was prepared directly from Arinto wine using a $3 \mathrm{kDa}$ cut-off ultrafilter (Centriplus YM-3 3000 MWCO membrane; Millipore, Billerica, MA), according to the manufacturer's instructions. Separation of the $<3 \mathrm{kDa}$ fraction from $>3 \mathrm{kDa}$ fraction was achieved by centrifugation at $3000 \mathrm{~g}$ for $8 \mathrm{~h}$. The $<3 \mathrm{kDa}$ fraction was reconstituted with water (pH adjusted to 2.8 ) to its original wine concentration, centrifuged at $10,000 \mathrm{~g}$ for $5 \mathrm{~min}$ and assayed for protein. The resulting $<3 \mathrm{kDa}$ wine fraction, containing no protein, was adjusted to $\mathrm{pH}$ 2.8 .

When appropriate, Arinto wine samples were thawed, centrifuged at $10,000 \mathrm{~g}$ for $5 \mathrm{~min}$ and selected organic acids gradually added to avoid a sudden drop in $\mathrm{pH}$. A solution of $\mathrm{NaOH}$ was used to counterbalance the drop in $\mathrm{pH}$, which was always kept equal to or above 2.8. After solubilising the required amount of the organic acid, the $\mathrm{pH}$ was adjusted to 2.8 , the solution was centrifuged at $10,000 \mathrm{~g}$ for $5 \mathrm{~min}$, its protein concentration determined and the $\mathrm{pH}$ adjusted to selected values.

In other solutions, a $20 \mathrm{mM}$, pH 2.8 solution of each organic acid under study was prepared. Enough solid Arinto wine protein was dissolved in each organic acid solution to achieve the desired concentration. The resulting solutions were centrifuged at $10,000 \mathrm{~g}$ for 5 min, their protein concentrations measured and the $\mathrm{pH}$ adjusted to selected values.

\subsection{Heat stability tests}

The heat stability tests of wine or protein samples were performed using the procedure recommended by Pocock and Rankine (1973), as described by Batista et al. (2009).

\subsection{Obtainment of tartrate precipitates and recovery of tartrate crystal deposits}

Tartrate crystal were obtained by cold stabilisation of the Arinto wine ( $\mathrm{pH} 2.8$ ) or its $<3 \mathrm{kDa}$ fraction ( $\mathrm{pH} 2.8$ ), both previously enriched with tartaric acid, $\mathrm{pH}$ 2.8. A mild cold stabilisation (achieved by a $24 \mathrm{~h}$ incubation at $4{ }^{\circ} \mathrm{C}$ ) was found to be suitable to precipitate tartrate crystals, which were pelleted by centrifugation $(10,000 \mathrm{~g}$, $5 \mathrm{~min}, 4^{\circ} \mathrm{C}$ ), washed with water and dissolved with a gentle warming in $2 \mathrm{ml}$ water, $\mathrm{pH}$ adjusted to $\mathrm{pH} 2.8$. These solutions were analysed by absorption spectroscopy using water or a $20 \mathrm{mM}$ solution of tartaric acid as controls. 


\subsection{Quantification of total phenolics}

Total phenolics were quantified by the Folin-Ciocalteau method, as described by Makkar, Bluemmel, Borowy, and Becker (1993), using tannic acid as the standard.

\section{Results}

Six organic acids, $\mathrm{L}(+)$-tartaric, $\mathrm{L}(-)$-malic, citric, succinic, gluconic and gallic acids, taken at a $20 \mathrm{mM}$ concentration, were analysed for their effect on protein haze formation in Arinto wine, naturally containing $280 \mathrm{mg}$ protein/l, or in an aqueous solution containing $280 \mathrm{mg} / \mathrm{l}$ of isolated Arinto wine protein. The analyses were undertaken over a $\mathrm{pH}$ range from 2.8 to 3.8. For comparative purposes, Arinto wine containing $280 \mathrm{mg}$ protein/l and an aqueous solution containing $280 \mathrm{mg} / \mathrm{l}$ of isolated Arinto wine protein were used as controls.

The results shown in Fig. 1A represent the pattern of protein haze formation of the Arinto wine (- - ) and of an aqueous solution containing the isolated Arinto wine protein (-- - - - ), as a function of $\mathrm{pH}$ (between $\mathrm{pH} 2.8$ and 3.8), as previously reported (Batista et al., 2009).

When a similar experiment was performed in which $20 \mathrm{mM}$ tartaric acid was added to all samples, a surprising result was ob- tained (Fig. 1A): new curves were produced for the pattern of haze formation as a function of $\mathrm{pH}$, not only in the case of wine enriched with $20 \mathrm{mM}$ tartaric acid (Fig. $1 \mathrm{~A} ;-\diamond-$ ), but also for the aqueous solution containing $280 \mathrm{mg} / \mathrm{l}$ Arinto wine protein and $20 \mathrm{mM}$ tartaric acid (Fig. 1A; - - - $\mathbf{-}---$ ), indicating a strong protective effect of tartaric acid at all $\mathrm{pH}$ values examined.

When $20 \mathrm{mM}$ malic acid (Fig. 1B), citric acid (Fig. 1C), succinic acid (Fig. 1D) or gluconic acid (Fig. 1E) was added to Arinto wine and to water containing Arinto wine protein, results similar to those achieved for tartaric acid (Fig. 1A) were obtained. In contrast, gallic acid $(20 \mathrm{mM})$ does not appear to exert any protecting effect upon the protein haze formation potential of the Arinto wine or of an aqueous solution containing $280 \mathrm{mg} / \mathrm{l}$ of the isolated Arinto wine protein (Fig. 1F).

To understand the stabilising effect exerted by organic acids, $10 \%(\mathrm{w} / \mathrm{v}) \mathrm{NaCl}$ was added to the isolated Arinto wine proteins dissolved in water (---4---) or in water containing $20 \mathrm{mM}$ tartaric acid (-口-) before submitting the samples to the heat stability test (Fig. 2A). The presence of the $\mathrm{NaCl}$ clearly removes the protective effect of tartaric acid on the isolated Arinto wine proteins, suggesting the possible participation of electrostatic interactions between wine proteins and organic acid. As a control, the data presented in Fig. 2B show that the addition of $10 \%(\mathrm{w} / \mathrm{v}) \mathrm{NaCl}$ to the Arinto wine (-口-) does not alter in a significant way the pattern of turbidity formation obtained during a subsequent heat stability test.
A

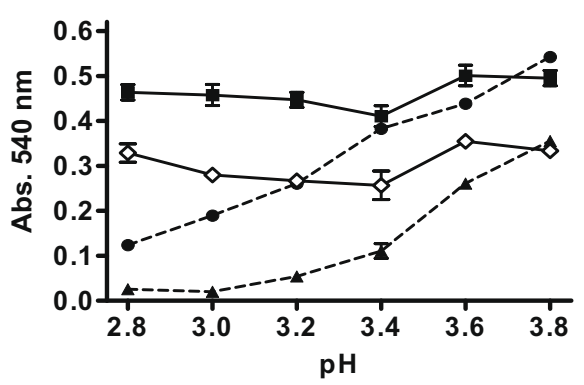

C
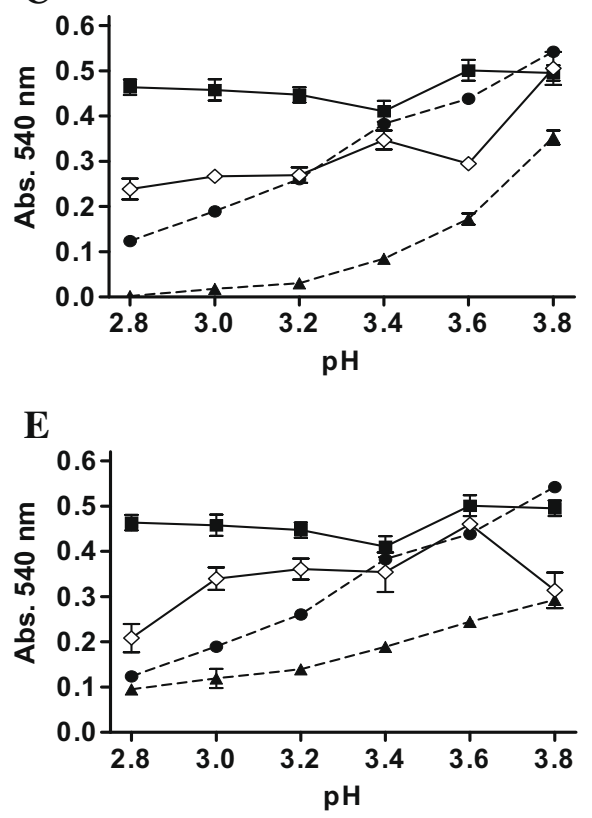

B

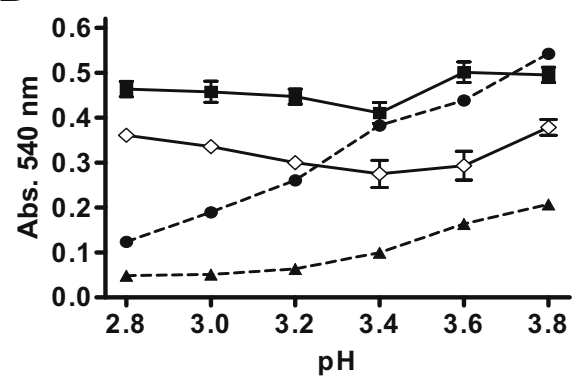

D

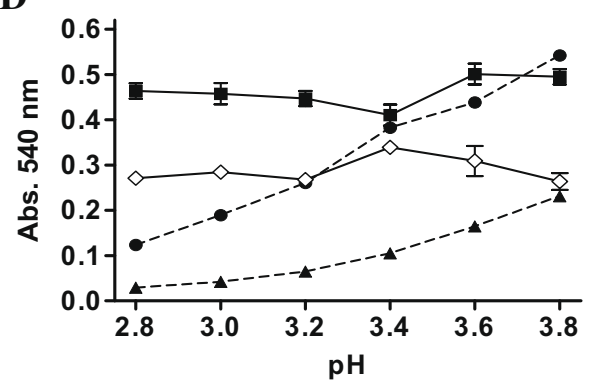

$\mathbf{F}$

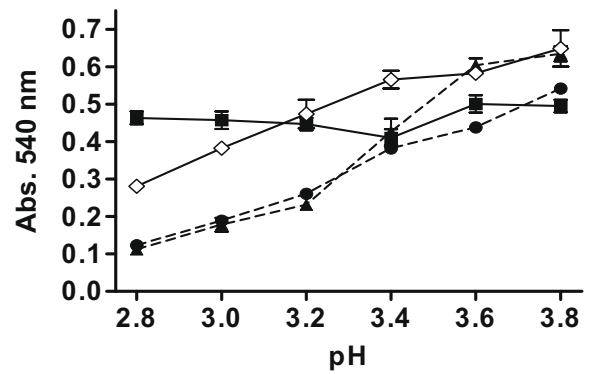

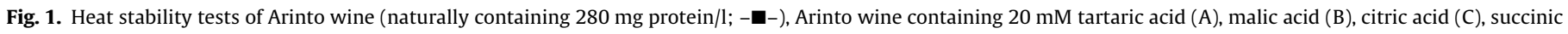

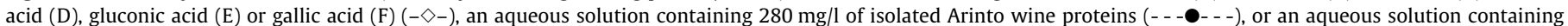

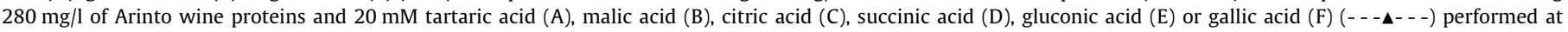
different $\mathrm{pH}$ values $(2.8,3.0,3.2,3.4,3.6$ and 3.8$)$. All experiments were performed in triplicate. Vertical bars represent plus or minus the standard deviation. 

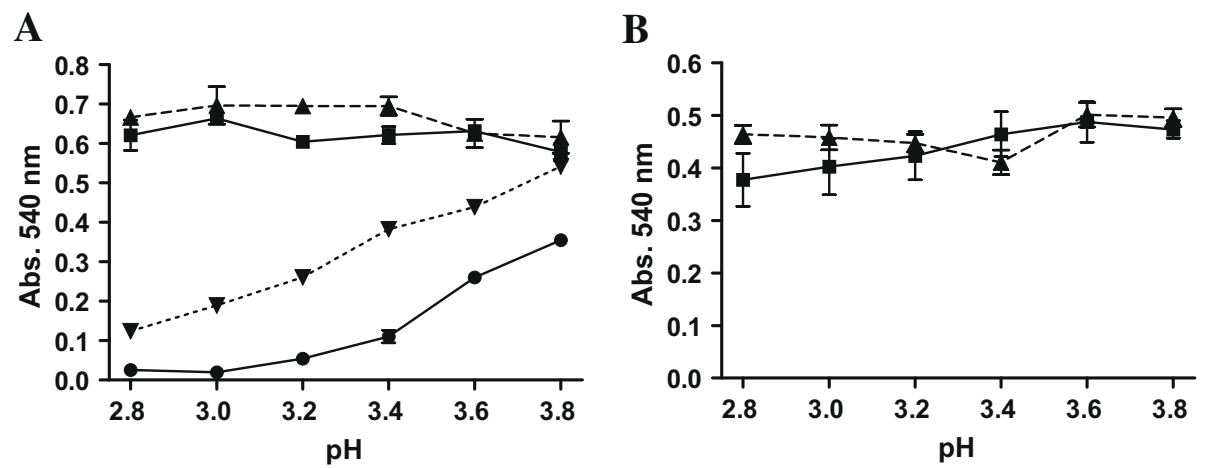

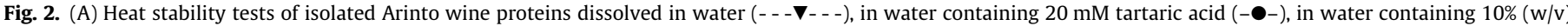

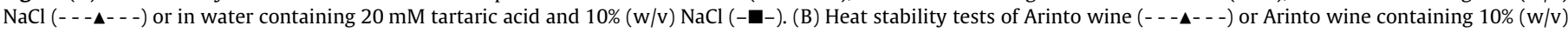

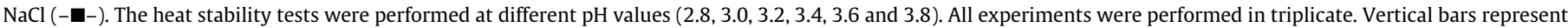
plus or minus the standard deviation.

A

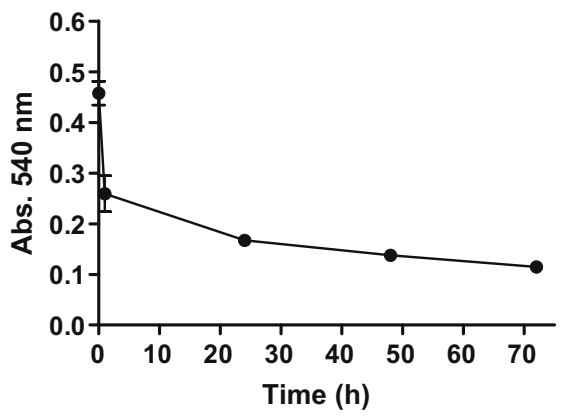

B

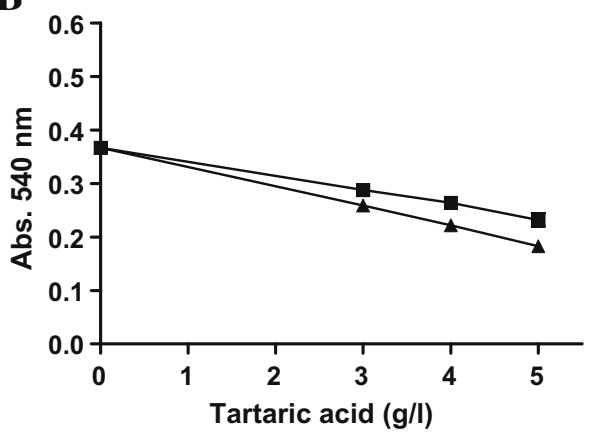

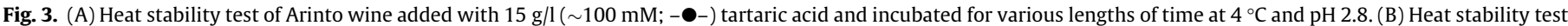

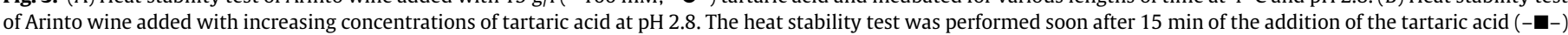
or after a $24 \mathrm{~h}$ incubation at $4{ }^{\circ} \mathrm{C}(-\mathbf{\Lambda}-)$. All experiments were performed in triplicate. Vertical bars represent plus or minus the standard deviation.

An attempted insight into the mechanism responsible for the stabilising effect of tartaric acid is summarised in the following experiments. The experiment illustrated in Fig. $3 \mathrm{~A}$ and B provides evidence that support three conclusions (1) the tartaric acid-induced stability of Arinto wine increases linearly with increasing concentrations of tartaric acid between 0 and $5 \mathrm{~g} / \mathrm{l}$ (a molecular mass of $150.087 \mathrm{Da}$ for tartaric acid, means that a $20 \mathrm{mM}$ concentration corresponds to approximately $3 \mathrm{~g} / \mathrm{l}$ ); (2) the stabilising effect is more pronounced if the wine plus tartaric acid is incubated for $24 \mathrm{~h}$ at $4{ }^{\circ} \mathrm{C}$ prior to performing the heat stability test; (3) the incubation at $4{ }^{\circ} \mathrm{C}$ of Arinto wine with $15 \mathrm{~g} / \mathrm{l}$ $(\sim 100 \mathrm{mM})$ tartaric acid for periods up to $72 \mathrm{~h}$ results in a biphasic curve: there is a sharp increase in stability during the first minutes of the incubation of Arinto wine minus tartaric acid at $4{ }^{\circ} \mathrm{C}$, followed by a prolonged but gradual increment in stability for at least $72 \mathrm{~h}$.

At this point of the research, a major issue became determining if increased concentrations of tartaric acid above $5 \mathrm{~g} / \mathrm{l}$ ( $\sim 33.35 \mathrm{mM}$ ) would induce augmented levels of stability in the Arinto wine. With this aim, the experiment illustrated in Fig. 4A and B was performed: samples of Arinto wine, $\mathrm{pH} \mathrm{2.8,} \mathrm{were} \mathrm{incu-}$ bated for $24 \mathrm{~h}$ at $4{ }^{\circ} \mathrm{C}$ in the presence of exogenously added $0 \mathrm{~g} / \mathrm{l}$ (0 mM), $5 \mathrm{~g} / \mathrm{l}(\sim 33.35 \mathrm{mM}), 10 \mathrm{~g} / \mathrm{l}(\sim 66.7 \mathrm{mM}), 15 \mathrm{~g} / \mathrm{l}(\sim 100 \mathrm{mM})$, $20 \mathrm{~g} / \mathrm{l}(\sim 133.4 \mathrm{mM})$ and $50 \mathrm{~g} / \mathrm{l}(\sim 333.5 \mathrm{mM})$ tartaric acid. The tartrate crystals were pelleted and collected by centrifugation, as described in Section 2, the supernatant subjected to the heat stability test (Fig. 4A) and the pellet used to quantify total phenols by the Folin-Ciocalteau method (Fig. 4B) or its absorption spectra determined (Fig. 4C).
The data presented in Fig. 4A may be misleading in the sense that the highest tartaric acid concentration tested appears to induce in the Arinto wine a lower level of stability to the proteins than smaller concentrations. However, this observation is only apparent, since the increase in $A_{540}$ detected for the Arinto wine containing 20 and $50 \mathrm{~g} / \mathrm{l}$ of tartaric acid is due to solubility problems of the acid itself. The continuous increment in total phenols present in the tartrate crystals precipitate when Arinto wine is incubated in the cold, for $24 \mathrm{~h}$, in the presence of exogenously added tartaric acid concentrations from 0 up to $50 \mathrm{~g} / \mathrm{l}$, further suggests that the level of protein stability increases (or the protein haze formation potential decreases) with the concentration of tartaric acid, from 0 to at least $50 \mathrm{~g} / \mathrm{l}$. The data presented in Fig. 4A and $\mathrm{B}$ also demonstrate that as the Arinto becomes more and more stabilised, increased amounts of phenolics are removed from wine in the form of tartrate crystals. The combined absorption spectra of the compounds present in the tartrate crystals (at the minimum, tartaric acid and phenols) are presented in Fig. 4C for all the added tartaric acid concentrations.

To further analyse the composition of the tartrate crystal precipitates, a sample of Arinto wine ( $\mathrm{pH} 2.8$; containing $280 \mathrm{mg}$ protein/l) and a sample containing the $<3 \mathrm{kDa}$ fraction of the Arinto wine ( $\mathrm{pH} 2.8$; and therefore with no protein) were enriched with $20 \mathrm{mM}$ tartaric acid. Tartrate crystals were produced and collected as described in Section 2 and subsequently solubilised in water. The supernatants were set aside and used for further analyses. Tartrate crystals absorption spectra, determined against water (Fig. 5A), are essentially identical for both samples, suggesting that the wine phenolic compounds dragged along with the tartaric 
A

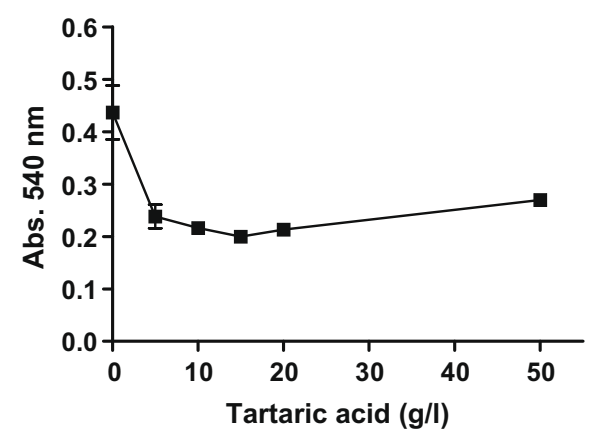

B

\begin{tabular}{|c|c|c|c|c|c|}
\hline & \multicolumn{5}{|c|}{$\begin{array}{c}\text { Tartrate crystal precipitates obtained from Arinto wine treated with } \\
\text { exogenously added tartaric acid }\end{array}$} \\
\hline & $5 \mathrm{~g} / \mathrm{l}$ & $10 \mathrm{~g} / \mathrm{l}$ & $15 \mathrm{~g} / \mathrm{l}$ & $20 \mathrm{~g} / \mathrm{l}$ & $50 \mathrm{~g} / \mathrm{l}$ \\
\hline $\begin{array}{c}\text { Total phenols ( } \mu \text { g tannic } \\
\text { acid/ml) quantified by } \\
\text { the Folin-Ciocalteau } \\
\text { method }\end{array}$ & $10.74 \pm 0.95$ & $11.69 \pm 1.42$ & $13.63 \pm 0.30$ & $13.80 \pm 0.33$ & $15.74 \pm 0.98$ \\
\hline
\end{tabular}

C

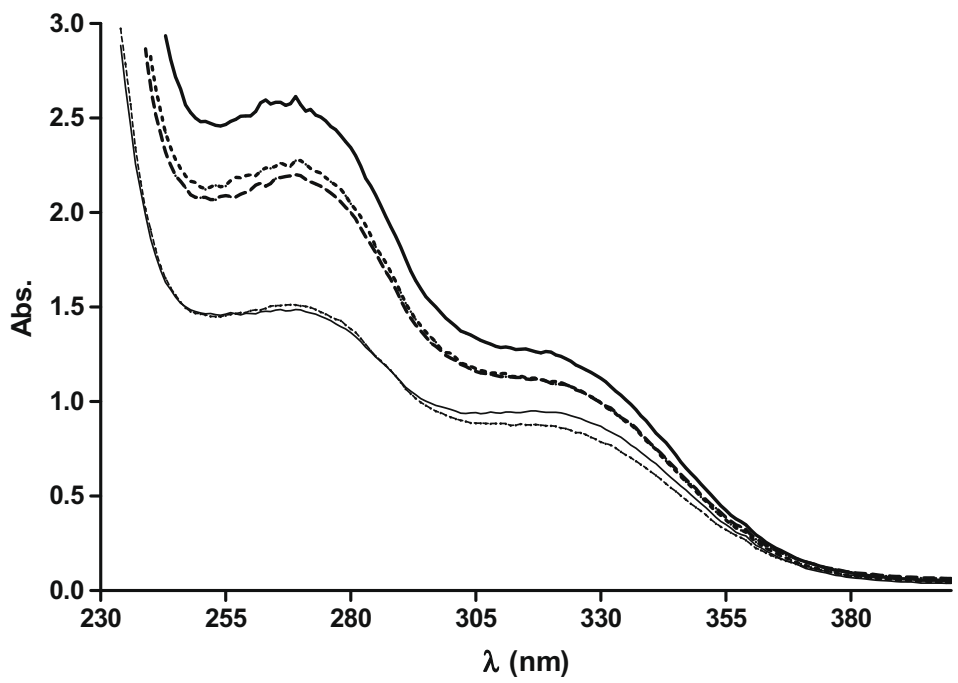

Fig. 4. Increasing concentrations of tartaric acid were added to samples of Arinto wine, $\mathrm{pH} 2.8$, and incubated for $24 \mathrm{~h}$ at $4{ }^{\circ} \mathrm{C}$. The tartrate crystals were pelleted and collected by centrifugation. The supernatant was subjected to the heat stability test (A) and the pellet used to quantify total phenols by Folin-Ciocalteau method (B) or its absorption spectra determined $(-, 5 \mathrm{~g} / \mathrm{l} ;---, 10 \mathrm{~g} / \mathrm{l} ;---, 15 \mathrm{~g} / \mathrm{l} ; \ldots-., 20 \mathrm{~g} / \mathrm{l} ;-, 50 \mathrm{~g} / \mathrm{l})$ (C). All experiments were performed in triplicate. Vertical bars in A represent plus or minus the standard deviation.

crystals are present in the $<3 \mathrm{kDa}$ Arinto wine fraction and that there are no proteins involved. The same absorption spectra were once again determined, but this time against $20 \mathrm{mM}$ tartaric acid, $\mathrm{pH}$ 2.8. The resulting absorption spectra, presented in Fig. 5B, show the absorption of the $<3 \mathrm{kDa}$ Arinto compounds (phenolic compounds? the $\mathrm{X}$ factor?) that are removed from the wine during tartrate crystal formation. Two absorption maxima are visible in these spectra: one at $c a .280 \mathrm{~nm}$, another at $c a .320 \mathrm{~nm}$ - a result that is compatible with the absorption spectra of phenolic compounds. As expected, Fig. 5C shows the absorption spectrum of $20 \mathrm{mM}$ tartaric acid, $\mathrm{pH} 2.8$, recorded against water.

Measuring protein concentration in a given sample is highly dependent on the protein composition in amino acids (Lucarini \& Kilikian, 1999; Sapan, Lundblad, \& Price, 1999). In addition, in a complex sample, such as a wine, there are countless compounds that may interfere in the quantification process (Lucarini \& Kilikian, 1999; Sapan et al., 1999). Phenolic compounds are probably the compounds that most interfere with protein quantification methods.

As mentioned above, the Arinto wine sample containing $20 \mathrm{mM}$ tartaric acid was subjected to tartrate precipitation, followed by centrifugation to separate supernatant from tartrate crystals. Tartrate precipitation caused a small reduction in soluble protein (measured by the Lowry method, as modified by Bensadoun and Weinstein, 1976), from $280 \pm 7 \mathrm{mg} / \mathrm{l}$ in the Arinto wine to $266 \pm 2.3 \mathrm{mg} / \mathrm{l}$ in the supernatant (Table 1). Although of little significance, this reduction may also be due to a loss in peptides, amino acids, phenolic and other compounds, which are known to interfere with this method. The same samples analysed by the Bradford method produced a reduction in protein from $270 \pm 12 \mathrm{mg} / \mathrm{l}$ for the Arinto wine to $262 \pm 5.3 \mathrm{mg} / \mathrm{l}$ for the supernatant. When the same methods were applied to the wine-derived, tartrate crystals dissolved in water, $7.20 \pm 0.63 \mathrm{mg}$ protein/l were detected by the modified Lowry method, but only $2.70 \pm 1.20 \mathrm{mg}$ protein/l were 

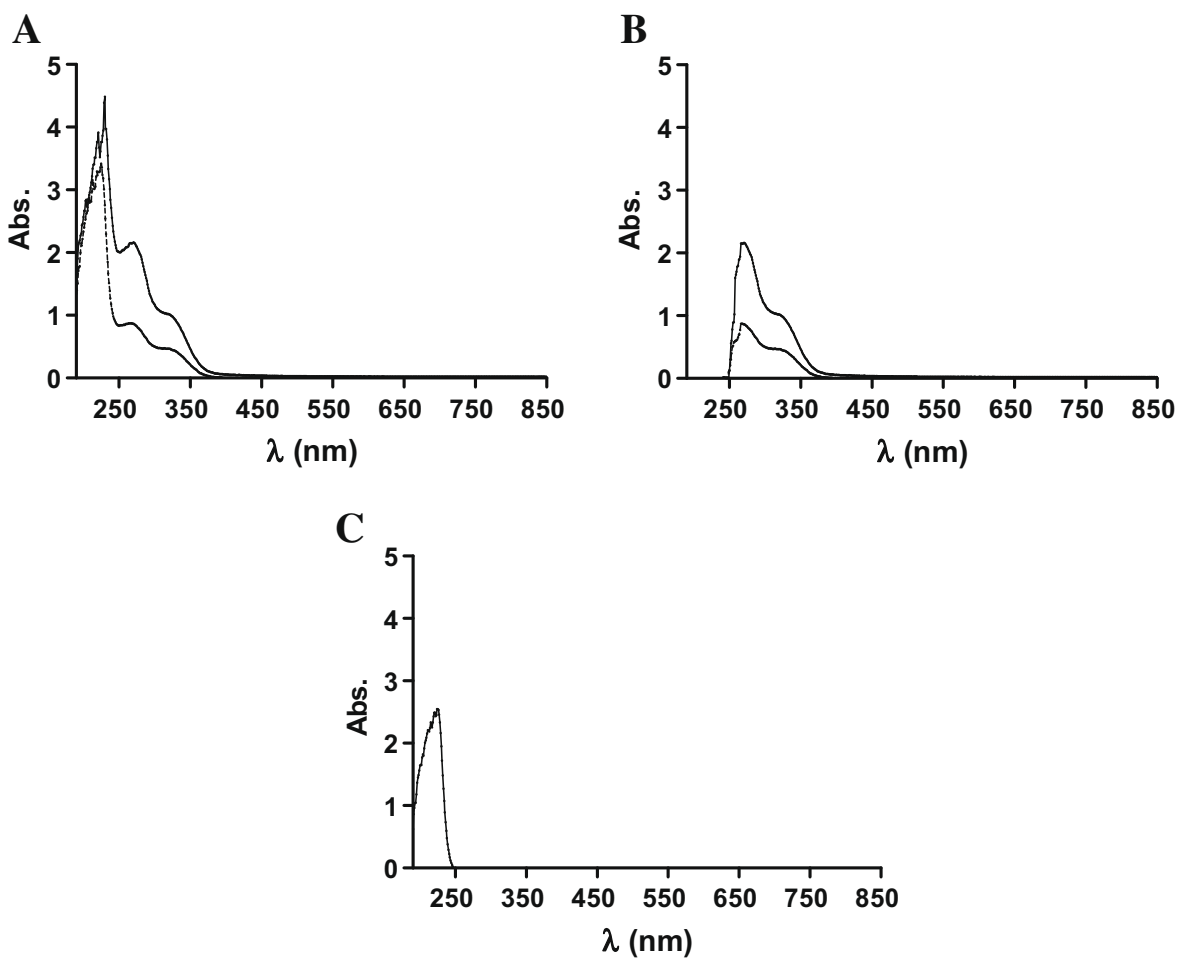

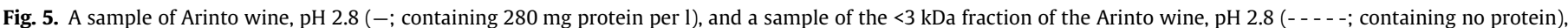

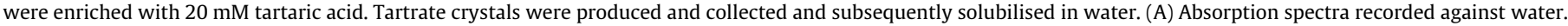

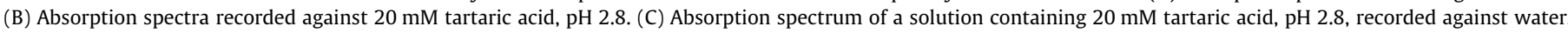

Table 1

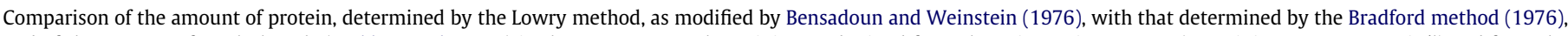

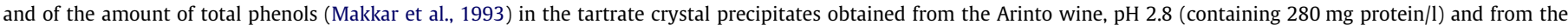
$<3 \mathrm{kDa}$ Arinto wine fraction, $\mathrm{pH} 2.8$ (containing no protein), both enriched with $20 \mathrm{mM}$ tartaric acid. All measurements were performed in triplicate.

\begin{tabular}{|c|c|c|c|}
\hline & \multicolumn{2}{|c|}{ Tartrate crystal precipitates obtained from } & \multirow[t]{2}{*}{ Control (20 mM tartaric acid) } \\
\hline & Arinto wine & $<3 \mathrm{kDa}$ Arinto wine fraction & \\
\hline Protein concentration (mg/l) measured by modified Lowry method & $7.20 \pm 0.63$ & $1.33 \pm 0.22$ & 0 \\
\hline Protein concentration $(\mathrm{mg} / \mathrm{l})$ determined by Bradford method & $2.70 \pm 1.2$ & $0.53 \pm 0.23$ & 0 \\
\hline Total phenols ( $\mu \mathrm{g}$ tannic acid/ml) quantified by the Folin-Ciocalteau method & $6.5 \pm 0.45$ & $4.3 \pm 0.32$ & 0 \\
\hline
\end{tabular}

quantified by the Bradford method (Table 2). Once again, the presence of phenolic compounds, peptides and free amino acids in the precipitate may be responsible, at least in part, for these values (Bensadoun \& Weinstein, 1976; Lucarini \& Kilikian, 1999).

The $<3 \mathrm{kDa}$ Arinto wine fraction (which does not contain protein) containing $20 \mathrm{mM}$ tartaric acid was also subjected to tartrate precipitation, followed by centrifugation to separate supernatant from tartrate crystals. In the supernatant, the apparent value estimated for the total protein was (when determined by the modified Lowry method) $13 \pm 0.7 \mathrm{mg} / \mathrm{l}$ or (when determined by the Bradford method) $0.5 \pm 0.13 \mathrm{mg} / \mathrm{l}$. When the same methods were applied to the $<3 \mathrm{kDa}$ fraction-derived, tartrate crystals dissolved in water, apparent protein values of $1.33 \pm 0.22 \mathrm{mg} / \mathrm{l}$ (modified Lowry method) or $0.53 \pm 0.23 \mathrm{mg} / \mathrm{l}$ (Bradford method) were estimated.

Analysis of the total phenols, by the Folin-Ciocalteau method, in the wine-derived and the $<3 \mathrm{kDa}$ fraction-derived tartrate crystals revealed concentrations of $6.5 \pm 0.45$ and $4.30 \pm 0.32$, respectively, expressed in $\mu \mathrm{g}$ tannic acid/ml. This method is also affected by the presence of amino acids, peptides and ascorbic acid (Makkar et al., 1993). The presence of phenolic compounds in tartrate precipitates is in good agreement with the available literature (Correa-Gorospe et al., 1991a, 1991b; Vernhet et al., 1999a).

\section{Discussion}

It is becoming increasingly evident that protein haze formation in wines is a multifactorial process. Besides the proteins themselves and the wine $\mathrm{pH}$, there appears to be an absolute requirement for one or more as yet unknown non-proteinaceous wine components, termed the $\mathrm{X}$ factor. In a fairly recent review, Waters and collaborators (2005) summarised the data published on a variety of wine components and factors about their potential effect on wine protein solubility. No reference was made and no experiments have been published that related protein haze formation with the levels of organic acids in wines.

Based on their importance and general abundance in wines, six organic acids were selected (Table 2): a tricarboxylic acid, three dicarboxylic acids and two monocarboxylic acids. Their structural formulae and $\mathrm{p} K_{\mathrm{a}}$ values are presented in Table 2. Tartaric and malic acids are the most abundant organic acids present in white wines (Lamikanra, Inyang, \& Leong, 1995). Citric and succinic acids are usually present in lower amounts in wines, except under special circumstances. Citric acid plays important roles at the biochemical and metabolic levels and is largely used by the food industry. Succinic acid accumulates in wines during fermentation 
Table 2

Structural formula, number of carboxyl groups and $\mathrm{p} K_{\mathrm{a}}$ values of the six organic acids selected to perform the analysis reported in this work.

\begin{tabular}{|c|c|c|c|c|}
\hline Common name & IUPAC name & Structural formula & Number of carboxyl groups & $\mathrm{p} K_{\mathrm{a}}$ values \\
\hline $\mathrm{L}(+)$-Tartaric acid & Dihydroxybutanedioic acid & & 2 & $\begin{array}{l}\mathrm{p} K_{\mathrm{a} 1}-3.01^{\mathrm{b}} \\
\mathrm{p} K_{\mathrm{a} 2}-4.05^{\mathrm{b}}\end{array}$ \\
\hline L(-)-Malic acid & Hydroxybutanedioic acid & & 2 & $\begin{array}{l}\mathrm{p} K_{\mathrm{a} 1}-3.46^{\mathrm{b}} \\
\mathrm{p} K_{\mathrm{a} 2}-5.05^{\mathrm{b}}\end{array}$ \\
\hline Citric acid & 2-Hydroxypropane-1,2,3-tricarboxylic acid & & 3 & $\begin{array}{l}\mathrm{p} K_{\mathrm{a} 1}-3.09^{\mathrm{b}} \\
\mathrm{p} K_{\mathrm{a} 2}-4.39^{\mathrm{b}} \\
\mathrm{p} K_{\mathrm{a} 3}-5.74^{\mathrm{b}}\end{array}$ \\
\hline Succinic acid & Butanedioic acid & & 2 & $\begin{array}{l}\mathrm{p} K_{\mathrm{a} 1}-4.18^{\mathrm{b}} \\
\mathrm{p} K_{\mathrm{a} 2}-5.23^{\mathrm{b}}\end{array}$ \\
\hline Gluconic acid & Pentahydroxyhexanoic acid & & 1 & $\mathrm{p} K_{\mathrm{a} 1}-3.6^{\mathrm{b}}$ \\
\hline Gallic acid & 3,4,5-Hydroxybenzoic acid & & 1 & $\mathrm{p} K_{\mathrm{a} 1}-4.26^{\mathrm{a}}$ \\
\hline
\end{tabular}

${ }^{a}$ IUPAC stability constants of metal-ion complexes (1979).

b Handbook of enology - the chemistry of wine: stabilization and treatments (2006).

and exhibits some characteristics that interfere with wine aroma (Peynaud \& Blouin, 1996; Ribéreau-Gayon et al., 2006). Gluconic acid is present in wines at even lower amounts than those of the acids mentioned above. Among the acids analysed, gallic acid is the only one bearing an aromatic ring. Being a phenolic acid, it is one of the compounds long suspected of interacting with the proteins, leading to their precipitation (Dawes, Boyes, Keene, \& Heatherbell, 1994; Waters et al., 2005, 2007). However, in a recent study using a model wine solution, Pocock et al. (2007) failed to detect any haze after heating the model wine solution in the presence of gallic acid. Nevertheless, this result must be interpreted with caution, due the presence of tartaric acid in the model solution.

A 20-mM concentration was selected because tartaric acid, the main wine organic acid, is naturally present in these beverages at similar concentrations (i.e., $4 \mathrm{~g} / \mathrm{l}$ ). This observation also explains the tartrate concentration commonly used in the preparation of wine model solutions. For comparative purposes, all organic acids were tested for their effect upon the wine proteins at 20-mM concentrations.

As reported in a previous paper (Batista et al., 2009), the pattern of protein haze formation of the Arinto wine does not change in a significant way over the range of $\mathrm{pH}$ values most commonly encountered in wines, i.e., between $\mathrm{pH} 2.8$ and 3.8. However, an aqueous solution containing an identical concentration of isolated Arinto wine protein produced a pattern of protein haze formation that is virtually identical to that of Arinto wine at high $\mathrm{pH}$ values, but strikingly different at low $\mathrm{pH}$ values. These protein haze differ- ences were shown to be independent of the ionic strength divergence between wine and water (Batista et al., 2009) and formed the basis for the proposal on the existence of at least two different molecular mechanisms responsible for the heat-induced precipitation of the Arinto wine proteins: one operating only at the higher $\mathrm{pH}$ values, that appears to result from reduced solubility of the proteins in the vicinity of their isoelectric points; another prevailing at the lower $\mathrm{pH}$ values, but possibly operating also at other $\mathrm{pH}$ values, that is due to the presence of the X factor (Batista et al., 2009).

When such experiments were repeated in the presence of $20 \mathrm{mM}$ tartaric, malic, citric, succinic or gluconic acids, two new curves were obtained, essentially parallel to the corresponding ones obtained in the absence of added organic acid, indicating a strong protective effect of the acid at all $\mathrm{pH}$ values examined (Fig. 1). It is as though the effect (or a part of it) of the X factor on protein haze formation was abolished by the presence of $20 \mathrm{mM}$ organic acid, leaving the isoelectric mechanism as the only one (or the prominent one) operating under these conditions. A direct consequence of this effect relates to the common use of tartaric acid in wine model solutions, based on the, now demonstrated to be false, assumption of no interference between the acid and the wine proteins in what constitutes haze formation. The results of such experiments may now be considered invalid or at least questionable.

Overall, all five organic acids analysed (Fig. 1A to E) exhibit a similarly strong protective effective on protein haze formation, either in wine or in isolated wine protein dissolved in water. No 
correlation could be established between the number of their carboxyl groups (Table 2) and the corresponding protective effect. However, considering only the Arinto wine protein dissolved in water (since the wine is a varying and extremely complex mixture of molecules with a huge and unpredictable number of interactions occurring among them), there appears to be a general trend of the protective effect exerted by the organic acid and the value of its $\mathrm{p} K_{\mathrm{a} 1}$ (Table 2): the higher its $\mathrm{p} K_{\mathrm{a} 1}$ value (and therefore, the closer to the $\mathrm{pI}$ of the wine proteins - see Batista et al., 2009), the lower the protective effect at the lower $\mathrm{pH}$ values, but the higher the protective effect at the higher $\mathrm{pH}$ values.

It is somewhat difficult to try to correlate the subtle differences among the five organic acids analysed in Fig. 1A-E with their protective effects on protein haze formation (isolated Arinto wine protein dissolved in water) with any of their characteristics depicted in Table 2. Fig. 6 illustrates a hypothetical explanation based on the net electric charge borne by both organic acids and wine proteins at each $\mathrm{pH}$ analysed, which depends obviously on the $\mathrm{p} K_{\mathrm{a}}$ values of the former and on the $\mathrm{pI}$ of the latter.

At low pH values (e.g., 2.8 and 3.0), the greater the $\mathrm{p} K_{\mathrm{a} 1}$ of the organic acid, the greater is the repulsion between organic acid (positive net charge) and wine proteins dissolved in water (positive net charge) and the smaller is the stabilising effect of the organic acid on protein haze formation. These results may be interpreted to mean that, under these conditions, the organic acid does not interact electrostatically with the wine proteins, and the otherwise stabilised proteins remain essentially free to interact with the $\mathrm{X}$ factor, inducing their haze formation potential. Thus, organic acids with high $\mathrm{p} K_{\mathrm{a} 1}$ values (4.18 for succinic acid, Fig. 1D; 3.60 for gluconic acid, Fig. 1E; and 3.46 for malic acid, Fig. 1B) do not stabilise the wine proteins to an extent as great as the organic acids with low $\mathrm{p} K_{\mathrm{a} 1}$ values (3.01 for tartaric acid, Fig. 1A; and 3.09 for citric acid, Fig. 1C), which, bearing a higher proportion of negative charges, are able to interact electrostatically with the positively charged proteins and stabilise them.

At high wine pH values (e.g., 3.6 and 3.8), the protein molecules approach the $\mathrm{pI}$, bearing no net charge or weak positive or negative charges. Under these conditions, organic acids weakly charged (such as tartaric acid and citric acid - Fig. 6) are unable to interact electrostatically in a strong manner with the proteins, producing a weaker stabilisation effect upon their protein haze formation potential (see Fig. 1A and C, respectively). Conversely, organic acids with a stronger charge at high pH values (such as gluconic, succinic and malic acids - Fig. 6) participate in stronger electrostatic inter-

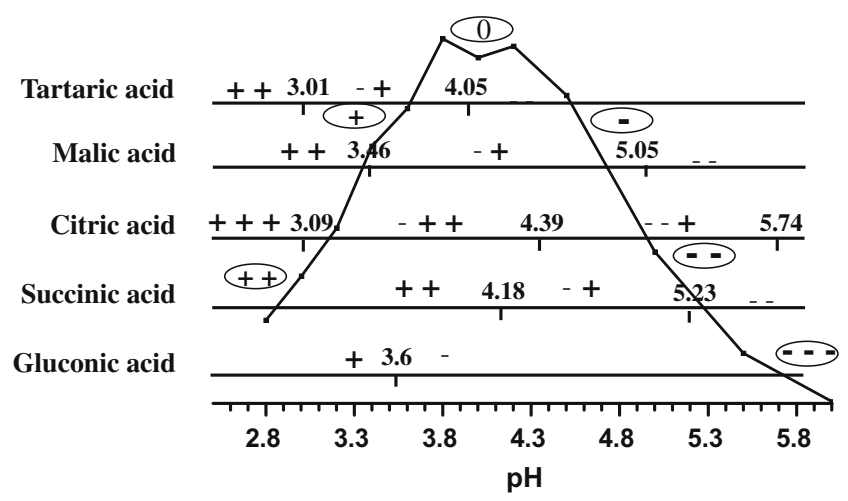

Fig. 6. Dominant net electrical charge borne by the organic acids (uncircled plus and minus signs) and the wine proteins (circled plus and minus signs) as a function of $\mathrm{pH}$, as predicted from their $\mathrm{p} K_{\mathrm{a}}$ and $\mathrm{pI}$ values, respectively. The curve presented for Arinto wine proteins is centred on their average $\mathrm{pI}$, as determined by 2D electrophoresis, and represents the pattern of protein haze formation as a function of $\mathrm{pH}$, when dissolved in water (Figs. 1 and 4, Batista et al., 2009). actions with the wine proteins, decreasing their haze formation potential (see Fig. 1E, D, and B, respectively).

Unlike the other five organic acids studied, gallic acid does not seem to exert any significant stabilisation of the protein, either in wine or in aqueous solution. On the contrary, for the higher $\mathrm{pH}$ values tested (i.e., 3.6 and 3.8), the presence of gallic acid seems to slightly increase protein instability.

A central question remains to be elucidated: why do tartaric, malic, citric, succinic and gluconic acids exert such a profound effect on wine protein stabilisation? A number of working hypotheses may be advanced. Firstly, organic acids are known to interact with a variety of wine components, such as, for example, phenolic acids, free amino acids, pectic compounds or tannins (and eventually the $\mathrm{X}$ factor), preventing their interaction with the proteins (Correa-Gorospe et al., 1991a, 1991b; Vernhet et al., 1999a, 1999b). This hypothesis does not apply in the experiments involving the isolated Arinto wine proteins, unless such compounds are adsorbed onto the surface of the proteins. Secondly, the organic acids may bind directly to the protein molecules, stabilising them, in a process that depends on the $\mathrm{p} K_{\mathrm{a}}$ values of the former, the $\mathrm{p} I$ of the latter and on the $\mathrm{pH}$ of the surrounding medium. The wine proteins are considered to be stable molecules at the wine $\mathrm{pH}$ (Batalia, Ernst, Roberts, \& Robertus, 1996; Waters, Peng, Pocock, \& Williams, 1995a, 1995b; Waters \& Høj, 1999), but become unstable under conditions that lead to haze formation. Thirdly, binding of the organic acids to the wine proteins may act as a shield, preventing further molecules subsequently binding to the proteins. As in the first hypothesis, this does not explain the experiments involving the isolated Arinto wine proteins.

In an attempt to understand the stabilising effect of the organic acids, tartaric acid was selected to perform a series of additional experiments for a number of reasons: it may be present in wines in high concentrations and it may easily precipitate, when subjected to low temperatures in the presence of potassium. Under these conditions, tartrate crystals are formed (Mira, 2004; Ribéreau-Gayon et al., 2006) which may associate with other wine components during their precipitation and sedimentation, making them unavailable to interact with the soluble proteins. It is possible that some wine proteins bind to the tartrate crystals as they form (Correa-Garospe et al., 1991b), but it remains unknown how tartrate crystal precipitation affects the wine protein composition.

In an attempt to understand the stabilising effect of the organic acids, Arinto wine or the Arinto wine isolated protein were treated with electrostatic interactions-cleaving agents and subjected to the heat stability test. The results obtained before (Batista et al., 2009) and in this work indicate that (i) protein haze formation either in wine or in water is not an electrostatically mediated process, it is an irreversible process that cannot be reversed by $\mathrm{NaCl}$, EDTA or EGTA treatments; (ii) high $\mathrm{NaCl}$ concentrations do not alter in a significant way the pattern of wine turbidity obtained during a subsequent heat stability test, but (iii) abolish the stabilising effect of the organic acid, suggesting that the protective effect on the wine proteins is apparently derived from electrostatic interactions established between the two kinds of molecules.

Attempted insights into the mechanism responsible for the tartaric acid-induced stability of Arinto wine indicate that the protective effect increases linearly with increasing concentrations of tartaric acid up to $5 \mathrm{~g} / \mathrm{l}$, with the incremental rate diminishing between 5 and $15 \mathrm{~g} / \mathrm{l}$. Above $15 \mathrm{~g} / \mathrm{l}$ tartaric acid does not solubilise well, leading to an increment in wine turbidity. Tartrate precipitation causes a small but non-significant reduction in the wine soluble protein, but removes a considerable amount of phenolic compounds, which are apparently involved in protein haze formation. Indeed, there is a gradual but continuous increment in the amount of phenolic material in the tartrate crystal precipitates, 
all the way from 0 to $50 \mathrm{~g} / 1$ tartaric acid. Spectroscopic analysis of the tartrate crystal precipitates reveals the co-precipitation of wine components with an absorption maximum between 260 and $280 \mathrm{~nm}$ and a pronounced shoulder between 210 and $230 \mathrm{~nm}$, spectral characteristics that are compatible with phenolics compounds. It is as though the cold-induced formation of tartrate crystals removes selected phenolic compounds (the $\mathrm{X}$ factor?) from solution, which become, in this way, unavailable to promote the protein haze formation by the heat stability test. The evidence presented excludes the removal/co-precipitation of the wine proteins along with tartrate crystals as an alternative explanation for the organic acid-haze forming protective effect.

Overall, the results obtained in the present work clearly indicate that organic acids with a common occurrence in wines, such as $\mathrm{L}(+)$-tartaric, $\mathrm{L}(-)$-malic, citric, succinic and gluconic acids, exhibit a stabilising effect upon the haze potential of the wine proteins. Furthermore, considering the two different molecular mechanisms responsible for the heat-induced precipitation of the Arinto wine proteins previously proposed (see above; Batista et al., 2009), the organic acid-induced protective effect operates at the level of the $\mathrm{X}$ factor and is therefore detected at all $\mathrm{pH}$ values studied (from 2.8 to 3.8 ).

Based on the evidence presented, a hypothesis explaining the mechanism underlying the stability effects exerted by organic acids upon the wine proteins may be formulated: organic acids, carrying a negative electric charged at the wine $\mathrm{pH}$, interact electrostatically with the wine proteins, positively charged at the wine $\mathrm{pH}$, all the way from 2.8 through to 3.8 . This interaction prevents the interaction of the $\mathrm{X}$ factor (presumably a compound(s) of phenolic nature) with the wine proteins. The organic acid remaining in the soluble, free form is also capable of interacting with the X factor, either in the presence or absence of protein, removing it from solution in the form of the tartrate crystal precipitate, thus stabilising the wine.

Organic acids may therefore be considered as another factor that modulates wine protein haze potential, contributing to the multifactorial nature of this process, but supporting, at the same time, the existence of the $\mathrm{X}$ factor and suggesting a phenolic nature for this(ese) enigmatic molecule(s).

\section{Acknowledgements}

The authors wish to thank Bacalhôa - Vinhos de Portugal, S.A. for providing the wine, and Dão-Sul for technical support. The financial support of Agência de Inovação S.A., under project KITPROT, is gratefully acknowledged.

\section{References}

Batalia, M. A., Ernst, S., Roberts, W., \& Robertus, J. D. (1996). The crystal structure of the antifungal protein zeamatin, a member of the thaumatin-like PR-5 family. Nature Structural Biology, 3, 19-23.

Batista, L., Monteiro, S., Loureiro, V. B., Teixeira, A. R., \& Ferreira, R. B. (2009). The complexity of protein haze formation in wines. Food Chemistry, 112, 169-177.

Belitz, H. D., \& Grosch, W. (1992). Química de los alimentos (2nd ed.). Zaragoza, España: Acribia.

Bensadoun, A., \& Weinstein, D. (1976). Assay of proteins in the presence of interfering materials. Analytical Biochemistry, 70, 241-250.

Blouin, J., Guimberteau, G., \& Audouit, P. (1979). Prévention des précipitations tartriques dans les vins par le procédé contact. Connaissance de la Vigne et du Vin, 2, 149-169.

Bradford, M. (1976). A rapid and sensitive method for the quantitation of microgram quantities of protein utilizing the principle of protein-dye binding. Analytical Biochemistry, 72, 248-254.

Correa-Gorospe, I., Polo, M. C., \& Hernandez, T. (1991a). Characterization of the protein and the phenolic fraction in tartaric sediments from wines. Food Chemistry, 41, 135-146.

Correa-Gorospe, I., Polo, M. C., Rodriguez-Badiola, E., \& Rodriguez-Clemente, R (1991b). Composition of tartrate precipitates in white wines used for making Spanish sparkling wine. Food Chemistry, 41, 69-79.
Dawes, H., Boyes, S., Keene, J., \& Heatherbell, D. (1994). Protein instability of wines: Influence of protein isoelectric point. American Journal of Enology and Viticulture, $45,319-326$.

Ferreira, R. B., Monteiro, S., Piçarra-Pereira, M. A., Loureiro, V. B., \& Teixeira, A. R. (2004). Engineering grapevine for increased resistance to fungal pathogens without compromising wine stability. Trends in Biotechnology, 22, 168-173.

Ferreira, R. B., Piçarra-Pereira, M. A., Monteiro, S., Loureiro, V. B., \& Teixeira, A. R. (2002). The wine proteins. Trends in Food Science \& Technology, 12, 230-239.

Gerbaud, V., Gabas, N., Blouin, J., Pellerin, P., \& Moutounet, M. (1997). Influence of wine polysaccharides and polyphenols on the crystallization of potassium hydrogen tartrate. Journal International des Sciences de la Vigne et du Vin, 2 , 65-83.

IUPAC stability constants of metal-ion complexes (1979). Part B: Organic ligands. Oxford: Pergamon Press.

Koch, J., \& Sajak, E. (1959). A review and some studies on grape protein. American Journal of Enology and Viticulture, 10, 114-123.

Lamikanra, O., Inyang, I. D., \& Leong, S. (1995). Distribution and effect of grape maturity on organic acid content of red Muscadine grapes. Journal of Agricultural and Food Chemistry, 43, 3026-3028.

Lucarini, A. C., \& Kilikian, B. V. (1999). Comparative study of Lowry and Bradford methods: Interfering substances. Biotechnology Techniques, 13, 149-154.

Makkar, H. P. S., Bluemmel, M., Borowy, N. K., \& Becker, K. (1993). Gravimetric determination of tannins and their correlations with chemical and protein precipitation methods. Journal of the Science of Food and Agriculture, 61, 161-165.

Maujean, A., Sausy, L., \& Vallée, D. (1985). Détermination de la sursaturation en bitartrate de potassium d'un vin. Quantification des effects collo protecteurs. Revue Francaise d'œnologie - cahier scientifique, 100, 39-49.

Mira, H. M. C. S. (2004). Influência da aplicação de resinas permutadoras de iões, PVI-PVP e proteínas vegetais nas características dos vinhos. PhD Thesis (294 pp.). Portugal: Technical University of Lisbon.

Peynaud, E. (1999). Enologia práctica. Conocimiento y elaboración del vino (3rd ed.). Madrid, España: Mundi-Prensa.

Peynaud, E., \& Blouin, J. (1996). The taste of wine: The art and science of wine appreciation. New York: John Wiley and sons.

Pocock, K., Alexander, G. M., Hayazaka, Y., Jones, P. R., \& Waters, E. J. (2007). Sulfate - A candidate for the missing essential factor that is required for the formation of protein haze in white wine. Journal of Agricultural and Food Chemistry, 55, 1799-1807.

Pocock, K. F., \& Rankine, B. C. (1973). Heat test for detecting protein instability in wine. Australian Wine Brewing and Spirit Review, 91, 42-43.

Ribéreau-Gayon, P., Glories, Y., Maujean, A., \& Dubourdieu, D. (2006). Handbook of enology - The chemistry of wine: Stabilization and treatments (2nd ed.). John Wiley \& Sons Ltd..

Rodriguez-Clemente, R., \& Correa-Gorospe, I. (1988). Structural, morphological, and kinetic aspects of potassium hydrogen tartrate precipitation from wines and ethanolic solutions. American Journal of Enology and Viticulture, 39, 169179.

Sapan, C. V., Lundblad, R. L., \& Price, N. C. (1999). Colorimetric protein assay techniques. Biotechnology and Applied Biochemistry, 29, 99-108.

Tanahashi, H., Nishino, H., \& Kazumoto, T. (1992). Nucleation and growth of potassium bitartrate in wine. Journal of Chemical Engineering of Japan, 25, 342-344.

Vallée, D., Bagard, A., Salva, G., Raoulx-Pantalacci, N., Bourde, L., Lavergne, C., et al. (1995). Determination of the temperature of saturation, of the field of supersaturation and of the "rules" of stability towards the calcium tartrate in wines. Journal International des Sciences de la Vigne et du Vin, 29, 143-158.

Vernhet, A., Dupre, K., Boulange-Petermann, L., Cheynier, V., Pellerin, P., \& Moutounet, M. (1999a). Composition of tartrate precipitates deposited on stainless steel tanks during the cold stabilization of wines. Part I: White wines. American Journal of Enology and Viticulture, 50, 391-397.

Vernhet, A., Dupre, K., Boulange-Petermann, L., Cheynier, V., Pellerin, P., \& Moutounet, M. (1999b). Composition of tartrate precipitates deposited on stainless steel tanks during the cold stabilization of wines. Part II: Red wines. American Journal of Enology and Viticulture, 50, 398-403.

Waters, E. J., \& Høj, P. (1999). Grape proteins involved in white wine instability: A short review of current knowledge and future perspectives. In Colloids and mouthfeel in wines (pp. 41-49). France: Lallemand SA.

Waters, E. J., Alexander, G., Muhlack, R., Pocock, K. F., Colby, C., O'Neill, B. N., et al. (2005). Preventing protein haze in bottled wine. Australian Journal of Grape and Wine Research, 11, 215-225.

Waters, E., Pocock, K., Alexander, G., Hayazaka, Y., Jones, P., Muhlack, R., et al. (2007). How can wine protein haze formation be best controlled or prevented? In Macromolecules and secondary metabolites of grapevine and wine (pp. 137143). Paris: Intercept Publishers.

Waters, E. J., Peng, Z., Pocock, K. F., \& Williams, P. J. (1995a). Proteins in white wine. I: Procyanidin occurrence in soluble proteins and insoluble protein hazes and its relationship to protein instability. Australian Journal of Grape and Wine Research, 1, 86-93.

Waters, E. J., Peng, Z., Pocock, K. F., \& Williams, P. J. (1995b). Proteins in white wine. II: Their resistance to proteolyses is not due to either phenolic association or glycosylation. Australian Journal of Grape and Wine Research, 1, 94-99. 